\title{
Distribution and habitat use of the Austral Rail Rallus antarcticus and perspectives on its conservation
}

\author{
JUAN MAZAR BARNETT, SANTIAGO IMBERTI and IGNACIO ROESLER
}

\section{Summary}

We present the results of searches for the Austral Rail Rallus antarcticus in Argentine and Chilean Patagonia between January 1998 and February 2006 and from subsequent visits. We surveyed 58 localities and found the rail in 22 , which collectively cover approximately $85 \mathrm{~km}^{2}$ of habitat. A maximum of 175 individuals were detected. This poorly known species was rediscovered in 1998; since then, it has been found in 18 additional localities, providing further data on distribution, habitat and seasonal movements. During the searches, we found that the species faces different threats, such as reduction of wetlands due to cattle grazing, burning and abnormal water management, but also the presence of American mink Neovison vison. However, due to the lack of prior information we conclude that the species should be maintained as Vulnerable.

\section{Resumen}

Presentamos los resultados de la búsqueda de la Gallineta Chica Rallus antarcticus en la Patagonia argentina y chilena, entre enero de 1998 y febrero de 2006, y en subsiguientes visitas. Monitoreamos 58 localidades y encontramos a la gallineta en 22 de ellas, que en conjunto representan aproximadamente $85 \mathrm{~km}^{2}$ de hábitat. Fueron detectados un máximo de 175 individuos. Esta especie poco conocida fue redescubierta en 1998 y, desde entonces, la hallamos en 18 localidades adicionales, lo que proporciona datos extras sobre la distribución, el hábitat y sus movimientos estacionales. Durante los monitoreos detectamos que enfrenta diversas amenazas, como la reducción de los humedales debido al sobrepastoreo, la quema y al mal manejo del agua, pero también por la presencia del visón Americano Neovison vison. Sin embargo, debido a la falta de información previa llegamos a la conclusión de que la especie debe mantenerse en la categoría Vulnerable.

\section{Introduction}

Austral Rail Rallus antarcticus was until recently a poorly known and enigmatic inhabitant of southernmost South America —only known from about 20 specimens and with virtually no natural history data-and had been classified as "Endangered/Extinct" (Collar et al. 1992). At that time, the most recent record was from 1959 (Navas 1962). In January 1998 a small population was found along the middle reaches of the Chico River, Santa Cruz province, Argentina, and baseline information on habitat and vocalisations was gathered (Mazar Barnett et al. 1998). Following this rediscovery, targeted searches were conducted at other localities with suitable habitat throughout the region (Imberti and Mazar Barnett 1999, Mazar Barnett and Imberti 2002). The new records led to the re-evaluation of the species's conservation status, and it was downlisted from Critically Endnageed (Collar et al. 1994) to "Vulnerable" in 2000 (BirdLife International 2012). 
The rail inhabits marshy oases in Patagonian steppes. These oases are dominated by rushes Schoenoplectus [Scirpus] californicus, usually surrounded by wet meadows with tall and lush grass, and associated with a permanent water body. As enigmatic as the rail itself are the conjectured causes for the species's supposed decline. Threats as varied as overgrazing by sheep and cattle, harvesting of rushes, and desertification arising from drainage and filling (the eroded top soil being blown into the wetlands) had been blamed for destruction of the species's habitat (Fjeldså 1988, Taylor and van Perlo 1998). Predation by American mink Neovison vison may have also played a role in its apparent decline (Fraga 200o). Actual and current threats to the species are not yet fully clear but development of agriculture in suitable river valleys, harvesting of rushes and overgrazing have been suggested (BirdLife International 2012).

Very little remains known about the ecology of the Austral Rail, and relevant conservation measures cannot be devised easily. Here we report new findings, including known distribution, habitat requirements, vocalisations, and other natural history information. We also try to evaluate the reasons for the absence of the species from large areas dotted with seemingly suitable habitat and re-assess the threats that it faces. Based on these new data we analyse aspects of the rail's life history, re-evaluate its conservation status, and propose further conservation action.

\section{Methods}

\section{Study area}

Our surveys took place in the Argentine provinces of Chubut, Santa Cruz and Tierra del Fuego, and the Chilean regions X, XI and XII, from January 1998 to February 2006. Target areas were selected on the basis of prior familiarity with the region, from regional and topographic maps, and then refined with the aid of satellite imagery. Additionally, we located suitable habitat by interviewing landowners and visited some historical sites (as listed in Collar et al. 1992). Most surveyed sites were situated within steppe habitats, both shrubby steppe in the north of the region, and the Magellanic steppe (sensu Pisano 1974) in the south. These represent seral communities (Cabrera 1994).

\section{Census technique}

As the initial goal of surveys was to determine presence/absence, we used methodologies that maximised the chance of detection. Playback experiments were conducted using commercial recordings of three different vocalisations sequentially: natural calls, song and responses to playback (Imberti et al. 2009). The survey technique consisted of walking at moderate pace (c.2 km/hr) along the edge of rushes or grassy areas, following no predetermined route, playing 3-4 song bouts once or twice every $100-150 \mathrm{~m}$, waiting up to $20 \mathrm{~min}$ for a response. We varied this technique as little as possible from site to site according to season and the shape of habitat patches. Some localities were surveyed more than once if we felt it was necessary (e.g. bad weather conditions during the initial survey). A variable amount of time was spent at each locality, depending on its size, accessibility and evidence of the rail's presence. For larger areas of habitat we walked into the rushes to ensure thorough coverage. The censuses were conducted principally during early morning and late afternoon in order to avoid the strong winds that occur in the hotter hours of Patagonian days and to concentrate effort during the rail's presumed peak activity periods.

Our surveys were effectively 'rapid assessments' and made no attempt to make quantitative estimations of habitat variables or species abundance/density. We only gathered information on general characteristics of each habitat patch sufficient to make broad comparisons between sites. Although we attempted to visit at least one known locality every month of the year (conditions permitting) to ensure year-round coverage, our efforts were concentrated during spring and summer, the rail's supposed breeding season (Jaramillo et al. 2003), when we expected birds to be more readily detectable. 
Local people and landowners were interviewed to obtain data on the historic and current presence of the species and on the extent of marshland habitat, and current human uses of it. We also played recordings of vocalisations to interviewees (always playing Plumbeous Rail Pardirallus sanguinolentus as a control). We were thus confident that the interviews provided reliable and accurate information.

\section{Results}

In total, nearly $25,000 \mathrm{~km}$ of road were surveyed, covering the central-southern portion of Patagonia, an area south of an imaginary line stretching from Valdivia (Chile) to Trelew (Argentina) then south to Navarino Island, Chile. We visited 58 wetlands (Figure 1; Tables 1-2; Table S1 in the online supplementary material), some of which contained more than one patch of habitat. In spite of the huge total area surveyed (approximately $700,000 \mathrm{~km}^{2}$ ), rails were found at only 22 localities (Figure I), mainly in southern Patagonia: Santa Cruz Province, Argentina, and the XII Region, Chile. These localities constitute five geographically distinct subpopulations: 1) Magellanic steppe south of the Gallegos River and Coyle River Basins; 2) seven sites in the transitional region of the Torres del Paine-Glaciares 'complex', at the foothills of large granite massifs; 3 ) three sites (with a further three possible localities nearby) around Gobernador Gregores, along the Chico River Basin; 4) the Deseado River Basin (including El Pluma and Bosques Petrificados Natural Monument). The fifth subpopulation is along a coastal axis in north-eastern Patagonia. We treat them separately although none of the sites here seems to hold important numbers of individuals.

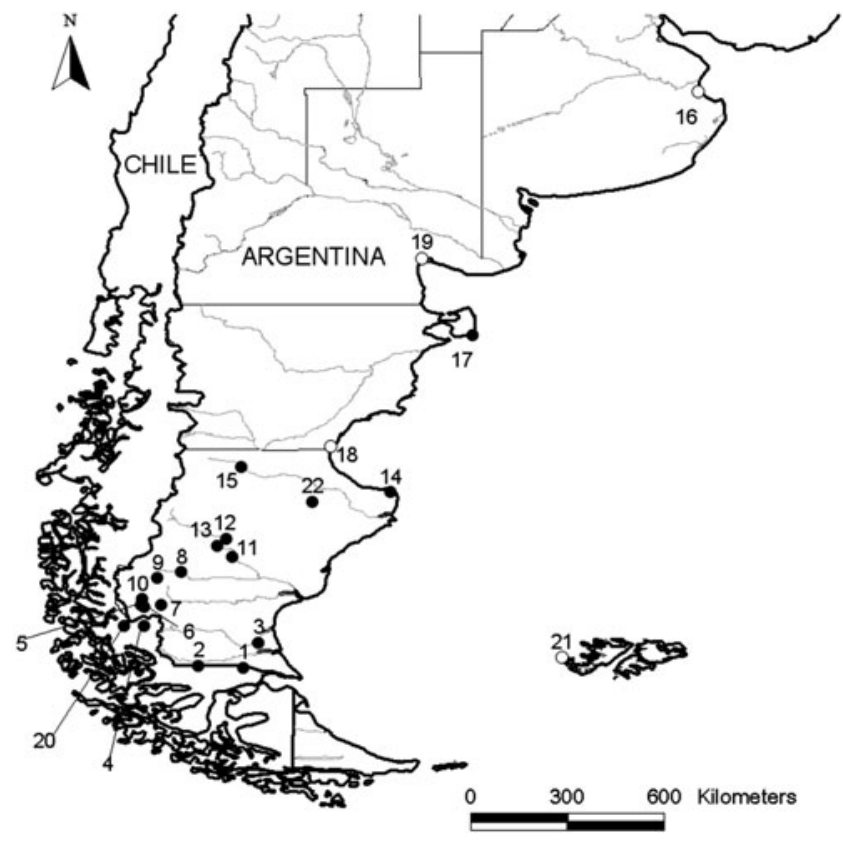

Figure 1. Localities were Austral Rail has been found. (•) resident populations, (०) migrant / vagrant records. I Ea. Brazo Norte; 2 El Zurdo; 3 Ea. Bella Vista Bitsch; 4 Torres del Paine National Park; 5 Ea. La Soledad; 6 Ea La Anita; 7 Laguna Nimez Municipal Reserve; 8 Laguna Balton; 9 Ea. Santa Margarita; 10 Ea. El Sosiego; I1 Ea. Cerro Ventana; 12 Ea. La Lucha; 13 Ea. La Angostura; 14 Ea. La Estrella; 15 Río Deseado/El Pluma; 16 Samborombon Bay; 17 Península Valdés; 18 Villa Rada Tilly; 19 San Antonio Oeste; 20 Estero Amalia 21Skip Harbour; 22 Bosques Petrificados Natura Monument. 


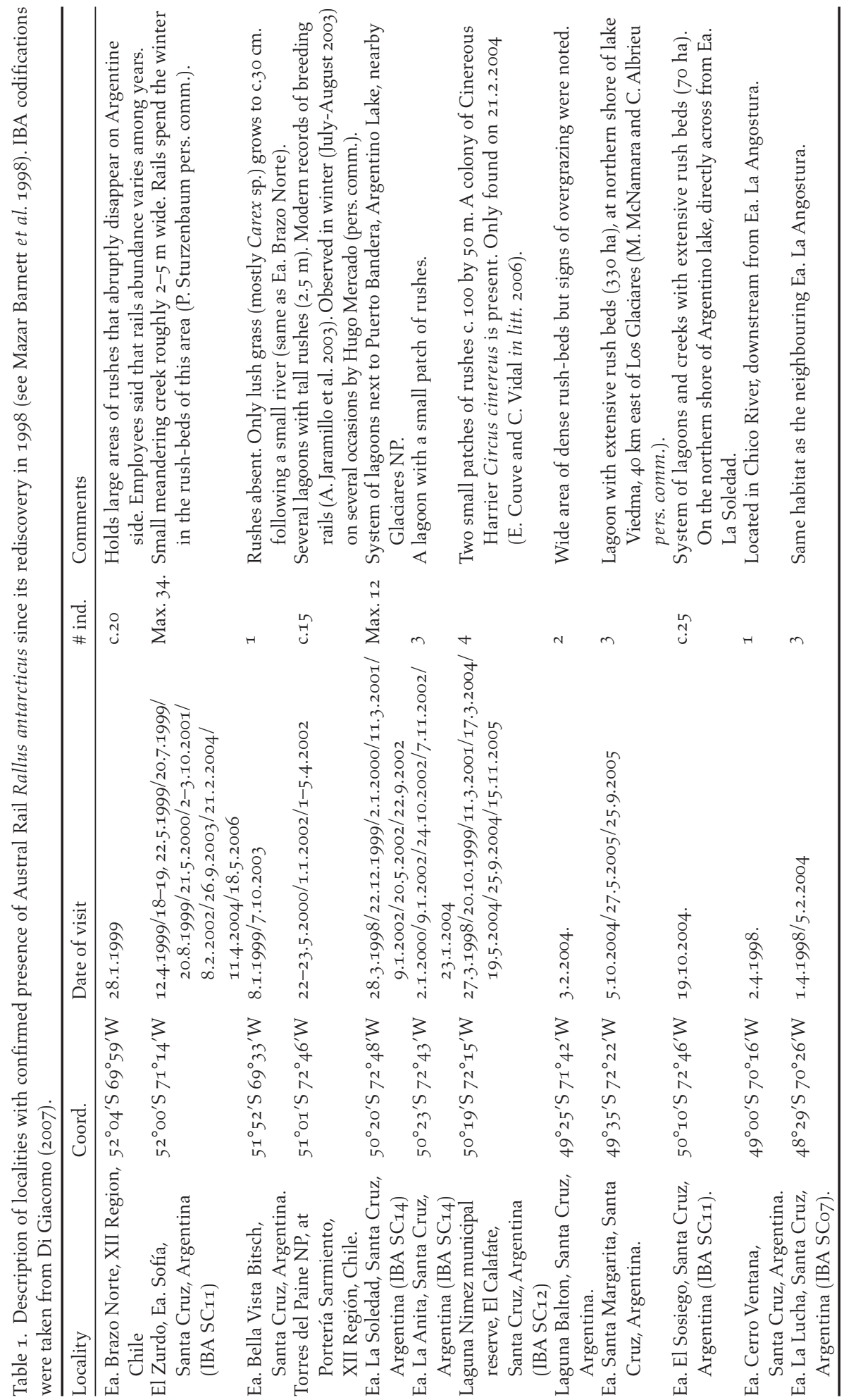




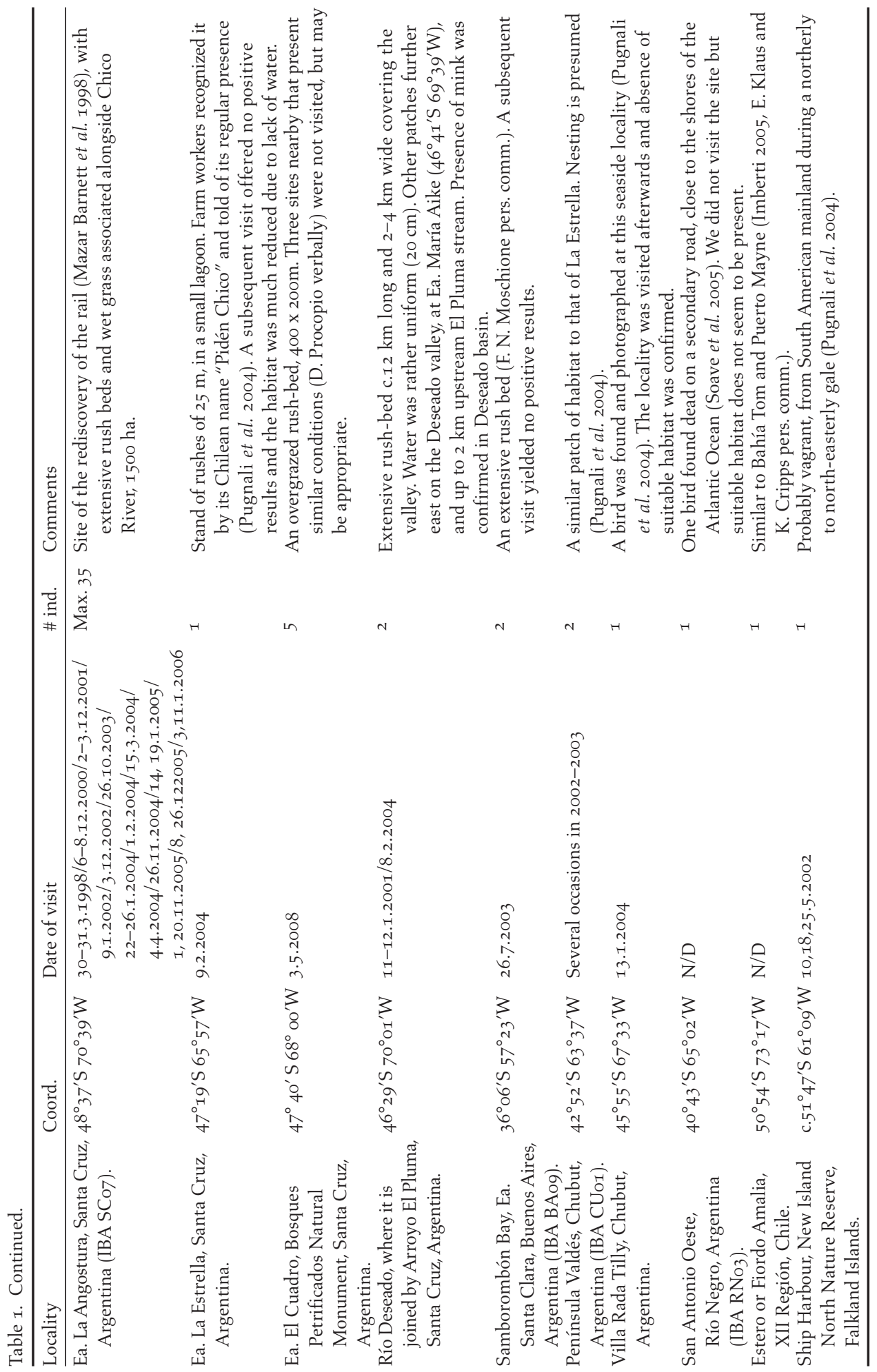


Table 2. Description of localities where the presence of the Austral Rail Rallus antarcticus is considered possible due to comments of local people and landowners, and habitat continuity with localities where the species is present.

\begin{tabular}{|c|c|c|}
\hline Localidad & Coord. & Comments \\
\hline $\begin{array}{l}\text { Estancia La Cabaña, } \\
\text { Santa Cruz, Argentina. }\end{array}$ & $48^{\circ} 34^{\prime} \mathrm{S} 70^{\circ} 29^{\prime} \mathrm{W}$ & $\begin{array}{l}\text { This and the following site are on the río Chico, only } \\
\text { a few km away from Ea. La Angostura and La Lucha. } \\
\text { We had no access to this site, although passing through } \\
\text { we noted only a few small patches of rush-beds. }\end{array}$ \\
\hline $\begin{array}{l}\text { Estancia La Carreta, } \\
\text { Santa Cruz, Argentina. }\end{array}$ & $48^{\circ} 57^{\prime} \mathrm{S} 70^{\circ} 13^{\prime} \mathrm{W}$ & $\begin{array}{l}\text { We only surveyed a patch of rush-beds. Workers recognised } \\
\text { recordings, differentiating them from Plumbeous Rail } \\
\text { P. sanguinolentus; they could hear it every spring and } \\
\text { summer. Formerly the rushes were burnt in winter, but } \\
\text { the rails seemed to return. Estancia Cerro Ventana is } \\
\text { located on the south side of the río Chico. }\end{array}$ \\
\hline $\begin{array}{l}\text { El Porvenir, Tierra del Fuego, } \\
\text { Chile. Laguna Deseada and } \\
\text { an unnamed lagoon at } \\
\text { Estancia Sarita. }\end{array}$ & $53^{\circ} 08^{\prime} \mathrm{S} 70^{\circ} 15^{\prime} \mathrm{W}$ & $\begin{array}{l}\text { Only places with concentrations of Schoenoplectus sp. } \\
\text { rushes in the island, but highly overgrazed. An animal } \\
\text { or bird was attracted to playback at the first lagoon, } \\
\text { but stayed among the rushes, without calling or exposing } \\
\text { itself. We believe this could have been a rail, even though } \\
\text { it remained silent. }\end{array}$ \\
\hline $\begin{array}{l}\text { Navarino Island, XII Región, } \\
\text { Chile. }\end{array}$ & $55^{\circ} \mathrm{Oo} \mathrm{o}^{\prime} \mathrm{S} 67^{\circ} 3 \mathrm{O}^{\prime} \mathrm{W}$ & $\begin{array}{l}\text { Locals identified the rail's call, mentioned the presence } \\
\text { of habitat where the two rail species are found in the } \\
\text { south of the island (near Windhond Bay), an area we } \\
\text { could not survey. The northern portion of the island } \\
\text { was surveyed. Ricardo Rozzi has an unconfirmed record, } \\
\text { around Cape Horn (S. McGehee pers. comm.). }\end{array}$ \\
\hline
\end{tabular}

The total area of suitable habitat at sites where rails have been found (area of occupancy) totals as little as c. $85 \mathrm{~km}^{2}$ and the maximum count of the species from all localities amounts to approximately 175 individuals. Although we do not suggest that these numbers reflect actual range and population, they are nevertheless a striking indication of the patchiness of the species's habitat and apparent rarity.

\section{Habitat characteristics and requirements}

All localities where we found rails share a number of characteristics, and, overall, look very similar to one another. There are similarities in plant species, physiognomy and bird communities (some or all of Wren-like Rushbird Phleocryptes melanops, Many-coloured Rush-tyrant Tachuris rubrigastra, Spectacled Tyrant Hymenops perspicillatus, Marsh Wren Cistothorus platensis and Yellowwinged Blackbird Agelasticus thilius are present). All but one site comprises dense rush-beds, albeit of different sizes and shapes. All possess a dense layer of $30-40 \mathrm{~cm}$ of dead rushes, bent over to form a 'mattress', nourished annually by the dead plants of the previous season. The rails use this cover extensively and are known to breed there (see 'Breeding'). A varying amount of lush, damp grassy fields surround or fringe the rush-beds, sometimes dense and extensive, sometimes absent or heavily overgrazed (usually 5-15 $\mathrm{m}$ in width, but up to $150 \mathrm{~m}$ ). These grassy fields are dominated by Descheupsia poaeioide and also contain Ceratophyllum sp., Carex sp. and Alopecurus sp. The open areas are usually covered by milfoil Myriophyllum sp. The exception is the habitat at Estancia Bella Vista Bitsch, which consisted only of these grass fields.

All locations where rails have been found lie on alluvial plains subject to seasonal inundation, and open terrain subject to the influence of a major water body that feeds the rush-beds. This may be a large river, rivulets and springs, or lakes and lagoons. These open plains favour the development of a complex mosaic of open grass and patches of rushes, which seem to form the key 
environment favoured by the rails. The extent of this habitat mosaic varies seasonally, yearly and between sites. Wetlands are very patchily distributed throughout the entire region surveyed, and only 28 (c. $48 \%$ ) out of 58 sites visited contained the above characteristics.

In the Chilean fjords, there are two historical localities (Bahía Tom and Puerto Mayne) and a recent record (Estero Amalia, Table I) whose habitats differ considerably from other rail sites, mostly comprising very humid forest with extensive peat bogs with Sphagnum sp., scattered concentrations of Juncus sp. and small ponds; only rarely are there anything resembling rush beds.

Interestingly, Todos Los Santos Lake appears to be the only historical locality situated within the forested region (see comments in Mazar Barnett et al. 1998). We were unable to check that area, but rails were not found at several sites with similar habitat along national road $\mathrm{N}^{\circ}$.

\section{Seasonality and movements}

It has been postulated that Austral Rail migrates following the breeding season (Collar et al. 1992): three valid historical records from Buenos Aires province would seem to support this (Mazar Barnett et al. 1998). We have detected rails at most sites during the austral spring, summer, and autumn, but never during July-September, although there are records during July-August in Torres del Paine National Park (H. Mercado pers. comm.). In our experience and judgment, Austral Rail disappears from sites where the habitat is not extensive and becomes unfavourable during freezing winter conditions (e.g. El Zurdo), yet is apparently resident at those that do not suffer such severe change (e.g. Torres del Paine National Park), where the large rush-beds do not completely freeze and thus afford year-round protection. Rails have been observed feeding there over ice-frozen lagoons (H. Mercado pers. comm.). At Todos Los Santos Lake it was also apparently resident, as can be inferred from the comments of Dr Wolffhügel (in Johnson 1965). Compelling evidence of seasonal movements comes from the observations of a pair at Valdes Peninsula, which were present during autumn, but not after June, then returned the following spring (Pugnali et al. 2004). Intra-year variation in the harsh climatic conditions of the southernmost part of the species' range probably determines the extent of such seasonal movements. The recent record from Samborombón Bay, in the Pampas region (Di Giacomo 2007), can only be assumed to be a winter visitor. Records from Rada Tilly, San Antonio Oeste and the Falkland Islands (Malvinas), possibly vagrants, also strongly indicate seasonal movements.

\section{Breeding}

Active nests containing eggs were found at Torres del Paine National Park in November 2000 and December 2001 (Jaramillo et al. 2003). Both nests were placed on a mattress of dead rushes inside a dense rush-bed. The measurements of five eggs ranged from $23.8-24.8 \times 33.7-35.5 \mathrm{~mm}$ (R. Matus in litt. 2002). A young chick covered in dark down was found dead in November 2001, seemingly predated by a Cinereous Harrier Circus cinereus or a Brown-hooded Gull Chroicocephalus maculipennis ( $\mathrm{H}$. Mercado pers. comm.). Based on these dates, we estimate that the breeding season starts (at least in the southernmost part of its range) by early-to-mid October, but probably varies annually and locally.

For such a poorly known species, there have been a surprising number of breeding reports. Collar et al. (1992) stated that only the eggs mentioned by Oates (1901), from 'Central Chile', 'can be safely attributed to this species'. However, the measurements reported by Oates considerably exceed the maximum size of the Torres del Paine eggs. The other two nests reported by Hartert and Venturi (1909) from near Buenos Aires, 'remain doubtful' (Collar et al. 1992). Again, their measurements are larger than those of Torres de Paine, with the exception of one egg; however, since this egg was associated with the other (oversized) eggs, we cannot safely attribute it to Austral Rail. The remaining report is a set of six eggs from Fundo San Ignacio, Santiago, Chile, found on I November 1940 (Collar et al. 1992, R. Corado in litt. 2002). Yet again, their measurements fall outside the range for Austral Rail. In summary, we doubt the accuracy of the historical breeding records. 


\section{Discussion}

\section{Habitat use by humans and consequences}

Historically, the wetlands inhabited by Austral Rails have been heavily used by Patagonian farmers to support cattle and sheep, especially during winter, due to the richness of the grasses (see Fjeldsa 1988). Most of Patagonia has suffered, to some degree, a reduction in the marshy area of its wetlands (Borrelli et al. 1997). The rush-beds regularly have a $30-50 \mathrm{~cm}$ (and up to $100 \mathrm{~cm}$ ) fringe eaten away, usually by cattle (which sometimes venture into the marshes). The grassy fields are the most impacted areas of the rush-bed physiognomy (pers. obs.). Overgrazing results in lower water-retention capabilities (Oliva et al. 2001), and therefore a reduction in the extent of wet areas favoured by the rail. We did not find rails at five sites (Estancia Shotel Aike, Gallegos Chico River, Tecka River, Estancia María Cristina and El Porvenir) that appear to have their marshland habitat substantially reduced and modified. If the rail's absence is not due to American mink (e.g. El Porvenir), we believe that it might be due to overgrazing. In the steppes of Tierra del Fuego, overgrazing seems to have been more devastating, and several interviewees reported that taller grasses were present in some wet areas until about 30 years ago. The historical sites for the species in Tierra del Fuego had, at some point, similar habitat to that described for Estancia Bella Vista Bitsch in Santa Cruz. However, most of this has disappeared and, nowadays, only El Porvenir holds a small area of suitable Schoenoplectus rushes. We also received reports from local people who recall the presence in these areas of the Plumbeous Rail, a bird hardly seen any more in the northern (steppe) part of the island (Clark 1986, R. Matus pers. comm.).

In Central Chile, natural vegetation in several lowland areas has been severely disturbed due to firewood extraction, the spread of agriculture and cattle-ranching, while several rivers have been modified. Wetlands in this region have been generally drained for conversion to agricultural fields or industrial areas (J. C. Torres-Mura in litt. 2002). Austral Rail has not been recorded there since the late $19^{\text {th }}$ century (Collar et al. 1992, Jaramillo et al. 2003).

Burning and harvesting of rushes to promote spring growth and for hay production have been suggested as potential pressures, but both practices are only occasional nowadays.

\section{Possible causes of decline and diagnosis of current threats}

The lack of historical information about Austral Rail population trends conspire against appropriately determining the factors that may have played a role in the species' supposed decline. In Central Chile, it is clear that major habitat modification has occurred, leading to its virtual extinction there (J. Aguirre and F. Schmitt pers. comm.). The other factors that we consider could have affected the species in the past are: overgrazing and the resulting reduction in areas of marshy habitat; burning and harvesting of rushes, which (although we lack specific details) used to be much more widespread; potentially, the misuse of water resources leading to the drainage of some wetland areas; and invasive American mink.

At present, ongoing sheep- and cattle-grazing are probably still detrimental to the species' favoured habitat. Overgrazing is a potential threat at many sites, particularly at Estancia Bella Vista Bitsch and El Zurdo, due to their smaller wetlands, fed only by a stream. Some agricultural development occurred in the Chico River valley, Santa Cruz, but a more extensive plan to develop agriculture in the area of Gobernador Gregores now seems to be on hold. This area is not far from one of the key localities for the species (e.g. Estancia La Angostura) as well as several sites where the rail is known or suspected to occur.

The introduction of American mink was considered a possible cause of the rail's extinction in northern Patagonia (Fraga 2000). Even though very plausible, few data support this hypothesis. Mink farms operated in Chubut in the 1940s-1970s (Pagnoni et al. 1986). By 1973, following escapes from farms, mink were common in Los Alerces National Park, Chubut (Foerster 1973). There, mink were associated with declines and disappearances of groups of waterfowl (Anatidae, Phoenicopteridae, Podicipedidae, Rallidae, Furnariidae - by predating nests, chicks and adults) and coypu Myocastor 
coypus (Foerster 1973). In Tierra del Fuego, fur farms operated from 1948 to 1961 when animals were released into the wild and spread across island. Hence, mink exist in two apparently isolated populations in Patagonia: one extending from central Neuquén to the north of Santa Cruz province and another in Tierra del Fuego and nearby areas of Chile (Fasola et al. 2011).

The last records of rails for northern Patagonia are from 1959. After that, the species was not found until the late 1990s, when mink were already common as far north as Lanín national park, Neuquen (Chehébar and Porro 1998, Fasola 2009), but rails were never recorded again in northern Patagonia. Thus, an association between mink and rail decline seems likely, given the experiences reported elsewhere where mink is an invasive predator.

In southern Patagonia, mink seem to be present in the northern part of the Chilean regions of Aysén and Magallanes (Cerda Cordero 2008) which hold some of the most important populations of Austral Rail, but we still lack of information on whether mink reach those important areas. In Argentina, mink expansion reached northern Santa Cruz in the early 1980s (A. Johnson in A. Serret in litt. 2011), and Fasola et al. (2011) suggested mink were not present south of Pueyrredon Lake. Recent studies show that mink is more widespread in Santa Cruz (Fasola and Roesler unpubl. data), with populations in several river basins that are inhabited by the Austral Rail (e.g. Chico River Basin and the area of Viedma Lake in the north of Los Glaciares National Park). However, there is still no available information on mink densities in those parts of Santa Cruz. The expansion of mink has been recorded to affect another endangered species of Santa Cruz, and given the known severe impact caused by introduced mink on many bird species — notably including Hooded Grebe Podiceps gallardoi (Roesler et al. 2012) - its presence in areas inhabited by Austral Rail is cause for serious concern.

\section{Conservation status}

Austral Rail is now known to be much commoner than suspected by Collar et al. (1992) but has transpired to be rarer than we envisaged at the outset of our surveys. So what of the rail's conservation status? In assessing the rail according to the IUCN guidelines (IUCN Standards and Petitions Subcommittee 2010), we find it hard to determine whether criterion A is applicable, as there are now 'more' rails than there were before 1998. But we consider it unlikely that its population has declined more than $20 \%$ within the last 14 years (three generations), as stipulated for classification as Near Threatened or higher under criterion A, as no major changes have occurred or affected its habitat in this period. The species does not qualify as "Vulnerable" under criterion B2 as, although its Area of Occupancy is estimated to be less than $2,000 \mathrm{~km}^{2}$, the strict area estimation being actually $80 \mathrm{~km}^{2}$, it is known from more than ten locations and its range is not thought to meet the IUCN definition of 'severely fragmented'. The Area of Occupancy is estimated to have declined by at least one-third within the last 60 years compared with the former known distribution (see Collar et al. 1992), but the timing of that reduction is clearly unknown. It does however appear to continue to qualify as "Vulnerable" under criterion C2a(i) (total population of fewer than 10,00o mature individuals, inferred to be undergoing a continuing decline, and no subpopulation numbering more than 1,000 mature individuals), allowing for a very lax estimation of population numbers, though it could easily reach the thresholds for Endangered $(<2,500$ mature individuals, declining and no subpopulation with more than 250 mature individuals) under the same criterion. The species thus remains "Vulnerable" under criterion $\mathrm{C}_{2} \mathrm{a}(\mathrm{i})$, although further data on population and subpopulation size may show that it could qualify as "Endangered" under the same criterion. If future studies prove the existence of population decline due to expansion of American mink, with consequent loss of sub-populations and reduction in the number of mature individuals, the Austral Rail may well need to be reassessed as "Endangered".

\section{Key sites for the conservation of Austral Rail}

Currently, only five localities that hold Austral Rails are formally protected: Torres del Paine and Pali Aike National Parks, Bosques Petrificados Natural Monument, Península Valdés and Laguna Nimez. 
These sites do not include the most important populations of the rail. Moreover, in the case of Pali Aike the majority of the rush-bed lies just outside the park, in the contiguous Estancia Brazo Norte. The latter, and Estancia La Angostura hold two of the three most important populations. Even if not formally protected, both sites are currently safe due to responsible management of the habitat: the only use is light grazing. La Soledad and El Sosiego ranches are adjacent to Los Glaciares National Park, and even though some cattle graze in the area, these are rather few and the rush-beds are otherwise untouched. No particular targets need be devised for the protection of these sites, as they are already effectively safe. El Zurdo is the second-most important locality in terms of the total number of rails recorded. It is privately owned, and although the area has been heavily grazed, the habitat has not yet been altered to a great extent. It would be ideal to offer some protection to these marshes (and others such as Bella Vista Bitsch) in the framework of potential legislation governing grazing (see 'Habitat management and legislation'). At its main localities at least, the rail appears relatively safe. The area of El Pluma (upper Deseado River) encompasses nearly 50\% of the total suitable habitat and most likely holds an important population, but the presence of American mink here has been confirmed, which may be the cause of the lack of records there so far.

\section{Further surveys and research}

Historical localities, mainly in Chile, need resurveying. The most important is probably Todos Los Santos Lake and the Hacienda Cauquenes area. Next in line are Navarino Island (and the archipelagos to the south) and Estancia La Carreta, where locals recently gave apparently reliable information about the species. We believe that Estancias Cristina, El Galpón, San Lorenzo and Cóndor are firm candidates to hold rails and should be revisited. Of interest are the fjords and channels south of Chiloé Island, which are logistically difficult to reach and were surveyed only briefly by us. Areas such as Tecka and El Porvenir are also worth visiting again. We propose that surveys, aided by the use of playback, are best undertaken in Patagonia from late January to late May. The region of northern and central Chubut and Río Negro provinces (which lack historical records) needs to be scrutinised for suitable habitat. Winter sites such as Samborombón Bay and other sites in Buenos Aires province should also be monitored.

\section{Supplementary Material}

The supplementary materials for this article can be found at journals.cambridge.org/bci

\section{Acknowledgements}

We are very grateful to the American Bird Conservancy for financial support and patience. Our surveys were initially funded by a Conservation Award from the Neotropical Bird Club, and more recently by the Neotropical Grassland Conservancy. To the many owners and caretakers of some of the most remote estancias and Patagonian nooks and crannies, who always welcomed and assisted us (above all the Kusanovic family at Estancia La Angostura), our wholehearted thanks. Paola Imberti and Pablo Sturzenbaum helped with references, data, support and company in the field. Ricardo Matus provided us with details, records and company in the field. We thank René Corado and Lloyd Kiff for their assistance with the Western Foundation of Vertebrate Zoology collection. Hugo Mercado provided invaluable records and observations from Torres del Paine National Park. Kim and Tony Chater, Marcelo de Cruz, Natalie Goodall, Sonja Heinrich, Flavio Moschione, Germán Pugnali, Susana Queiro, Luis Segura, Pablo Tubaro, Diego Procopio, Marcos Baltuska, Richard White, Carlos Albrieu, Fabrice Schmitt, Nora Loekemeyer, Luis Benegas, Olga Vaccaro, Silvina Sturzenbaum, Diego Punta Fernández, Adrían Di Giacomo, Lali Fasola and many others provided help through comments, ideas, records, access to literature and much more. James Lowen revised and greatly improved the manuscript. 


\section{References}

BirdLife International (2012) Species factsheet: Rallus antarcticus. Cambridge, UK: Birdlife International. http://www.birdlife. org (accessed on 22 August 2012).

Borrelli, P., Oliva, G., Williams, M., Gonzales, L., Rial, P. and Montes, L. (1997) Sistema regional de soporte de decisiones. Río Gallegos, Argentina: Grupo interdisciplinario para el Sistema de Soporte de Decisiones Santa Cruz y Tierra del Fuego. PRODESER (INTA-GTZ).

Cabrera, A. L. (1994) Regiones fitogeográficas argentinas. Buenos Aires, Argentina: Encic. Arg. Agric. Jard. 2. Acme.

Cerda Cordero, J. (2008) Experiencia piloto de control del visón Aisen. Pp. 30-38 in A. Mann, ed. Vertebrados dañinos en Chile: desafíos y perspectivas. Actas del seminario taller, 8 de enero de 2008. Santiago, Chile: Universidad Santo Tomás.

Chehébar, C. and Porro, G. (1998) Distribución y estatus del Huillín (Lutra provocax) en el Parque Nacional Nahuel Huapi, Argentina. Vida Silv. Neotrop. 7: 99-106.

Clark, R. (1986) Aves de Tierra del Fuego y Cabo de Hornos. Buenos Aires, Argentina: L.O.L.A.

Collar, N. J., Gonzaga, L. P., Krabbe, N., Madroño Nieto, A., Naranjo, L. G., Parker, T. A. and Wege, D. C. (1992) Threatened birds of the Americas: the ICBP/IUCN Red Data Book. Cambridge, UK: International Council for Bird Preservation.

Collar, N. J., Crosby, M. J. and Stattersfield, A. J. (1994) Birds to watch 2: the world list of threatened birds. Cambridge, UK: BirdLife International. (BirdLife Conservation Series 4).

Di Giacomo, A. S., ed. (2007) Áreas importantes para la conservación de las aves en Argentina. Sitios prioritarios para la conservación de la biodiversidad. Buenos Aires, Argentina: Aves Argentinas/ Asociación Ornitológica del Plata. (Temas de naturaleza y conservación 5).

Fasola, L. (2009) Distribución, alimentación $e$ interacciones de dos mustélidos semiacuáticos en los bosques andino patagónicos: el Huillín (Lontra provocax), nativo, y el Visón Americano (Mustela vison), introducido. Tesis doctoral. Buenos Aires, Argentina: Universidad de Buenos Aires.
Fasola, L., Muzio, J., Chehébar, C., Cassini, M. H. and Macdonald, D. W. (2011) Range expansion and prey use of American mink in Argentinean Patagonia: dilemmas for conservation. Eur. J. Wildl. Res. 57: 283-294.

Fjeldså, J. (1988) Status of birds of steppe habitats of the Andean Zone and Patagonia. Pp. 81-95 in P. D. Goriup, ed. Ecology and conservation of grassland birds. Cambridge, UK: International Council for Bird Preservation (Technical Publication No. 7).

Foerster, R. (1973) Estudio integral sobre la presencia de visones (Mustela vison) en el Parque Nacional los Alerces y zona de influencia. Buenos Aires, Argentina: Centro de Documentación, Administraciónde Parques Nacionales. (Technical report).

Fraga, R. M. (200o) Introduced feral mink Mustela vison in Patagonia: a plausible cause of population declines in the Austral Rail Rallus antarcticus? Cotinga 13: 71-72.

Hartert, E. and Venturi, S. (1909) Notes sur les oiseaux de la République Argentine. Novit. Zool. 16: 159-267.

Imberti, S. and Mazar Barnett, J. (1999) El pidén austral Rallus antarcticus redescubierto en Chile. Bol. Chileno Ornitol. 6: 44-45.

Imberti, S. (2005) Distribución otoñal de aves marinas y terrestres en los Canales Chilenos. Anales del Instituto de la Patagonia (Chile) 33: 21-30.

Imberti, S., Areta, J. I., Mazar Barnett, J., Pugnali, G., Roesler, I., Monteleone, D., Casañas, H., and Rodriguez Goñi, H. (2009) Birds sounds of Argentina and adjacent areas: Patagonia, Antarctic and South Atlantic Islands. Norfolk, United Kindom: WildSounds and Seriema Editions.

IUCN Standards and Petitions Subcommittee (2010) Guidelines for using the IUCN Red List categories and criteria. Version 8.1. Gland, Switzerland: Prepared by the Standards and Petitions Subcommittee in March 2010. http://intranet.iucn.org/ webfiles/doc/SSC/RedList/RedListGuidelines.pdf (accessed on I July 2012). Jaramillo, A., Aguirre, J., Imberti, S. and Matus Navarro, R. J. (2003) Hallazgo de dos nidos 
de Pidén Austral Rallus antarcticus in Torres del Paine National Park, VII Neotropical Ornithological Congress, Termas de Puyehue, Chile 5-11 October.

Johnson, A. W. (1965) Birds of Chile and adjacent regions of Argentina, Bolivia and Peru. Buenos Aires, Argentina: Platt Establecimientos Gráficos.

Mazar Barnett, J. and Imberti, S. (2002) Austral Rail surveys and conservation. Unpublished report presented to the American Bird Conservancy.

Mazar Barnett, J., della Seta, M., Imberti, S. and Pugnali, G. (1998) Notes on the rediscovery of the Austral Rail Rallus antarcticus in Santa Cruz, Argentina. Cotinga 10: 96-101.

Navas, J. R. (1962) Reciente hallazgo de Rallus limicola antarcticus King (Aves, Rallidae). Neotrópica 8: 73-76.

Oates, E. W. (1901) Catalogue of the collection of bird's eggs in the British Museum, 1. London, U K: Taylor \& Francis.

Oliva, G., Noy-Meir, I. and Cibils, A. (2001) Fundamentos de ecología de pastizales. Pp. 83-10o in P. Borrelli and G. Oliva, eds. Ganadería ovina sustentable en la Patagonia Austral. Río Gallegos, Argentina: Inst. Nac. Tec. Agrop. Reg. Sur.

Pagnoni, G., Garrido, J. and Marin, M. (1986) Impacto económico y ambiental del visón Mustela vison (Schreber, 1877) en el norte de la Patagonia. Puerto Madryn, Argentina: CENPAT-CONICET. Dirección de Fauna de la Provincia de Chubut. (Informe Técnico 20).

Pisano, E. (1974) Estudio ecológico de la región continental sur del área andino patagonica. II. Contribución a la fitogeografía de la zona del Parque Nacional "Torres del Paine". Anales del Instituto de la Patagonia 5: 59-104.

Pugnali, G., Pearman, M., Escudero, G., Vaquero, D. and Chater, T. (2004) New localities for the Austral Rail Rallus antarcticus in Argentina, and first record from the Falkland Islands. Cotinga 22: 35-37.

Roesler, I., Imberti, S., Casañas, H. and Volpe, N. (2012) A new threat for the globally Endangered Hooded Grebe Podiceps gallardoi: the American mink Neovison vison. Bird Conserv. Internatn: 22: 383-388.

Soave, E. D., Soave, G. E. and Darrieu, C. A. (2005) Nuevo registro con material de la Gallineta Austral Rallus antarcticus en Argentina. Buenos Aires, Argentina: Libro de Resúmenes de la Reunión Argentina de Ornitología, 7-1o September.

Taylor, B. and van Perlo, B. (1998) Rails: a guide to the rails, crakes, gallinules and coots of the world. Robertsbridge, UK: Pica Press.

\section{JUAN MAZAR BARNETT \\ Aves Argentinas/Asociación Ornitológica del Plata, Matheu 1246/8 (C1249 AAB), \\ Buenos Aires, Argentina.}

\section{SANTIAGO IMBERTI}

Ambiente Sur. Rivadavia 780, Río Gallegos (9400), Santa Cruz, Argentina.

\section{IGNACIO ROESLER*}

Departamento de Ecología, Genética y Evolución, Facultad de Ciencias Exactas y Naturales, Universidad de Buenos Aires, Pabellón II Ciudad Universitaria (C1428EGA), Buenos Aires, Argentina.

*Author for correspondence; e-mail: roesler@ege.fcen.uba.ar

This paper is dedicated to the memory of Juan Mazar Barnett (1975-2012).

Received 25 August 2012; revision accepted 04 January 2013; Published online 17 June 2013 